\title{
Peran Social Networking Sites dalam meningkatkan Stakeholder Engagement: A Literature Review
}

\author{
Falah Muthiah ${ }^{1 *}$ \\ ${ }^{1}$ Program in Communication Science of Faculty of Social and Political Science, Universitas Indonesia \\ Jl. Margonda Raya, Pondok Cina, Kecamatan Beji, Kota Depok, Jawa Barat \\ E-mail: ${ }^{1}$ falah.muthiah@ui.ac.id
}

Received: June 2021; Accepted: October 2021; Published: December 2021

\begin{abstract}
The role of Social Networking Sites in ongoing communication becomes easier, especially to build stakeholder management and stakeholder engagement, provide information, and monitor information to manage the image and reputation of the company. This literature review aims to explore the role of Social Networking Sites in increasing stakeholder engagement. This research method is a literature review that uses journal reference sources sorted by the role of Social Network Sites in increasing Stakeholder Engagement. The results show that Social Network Sites on the platforms Facebook, Instagram, Twitter, and Youtube are tools to increase engagement with internal and external stakeholders to create relationships and improve the company's image and reputation. Social Network Sites play a role in building connections, relational relationships between customers, assessing the matrix for stakeholders, assessing company performance, assessing stakeholder participation, assessing marketing strategies, building relationship relationships, and forming customer loyalty. Online activities carried out by stakeholders are related to the image of the company's reputation, so that digital public relations and corporate communications must adequately manage it.
\end{abstract}

Keywords: Social Network Sites, Stakeholders, Engagement, Digital Public Relations, Reputation. Abstrak (Times New Roman, 11 pt Bold) (300 kata)

Peran Social Networking Sites dalam komunikasi yang berlangsung menjadi lebih mudah terutama untuk membangun stakeholder manajemen dan stakeholder engagement, serta dapat memberikan informasi juga pengawasan informasi dalam rangka menjaga citra dan reputasi pada perusahaan. Kajian literatur ini bertujuan untuk mengeksplorasi peran Social Networking Sites dalam meningkatkan stakeholder engagement. Metode penelitian ini adalah kajian literatur yang menggunakan sumber referensi jurnal yang disortir berdasarkan peran Social Network Sites dalam meningkatkan Stakeholder Engagement. Hasilnya menunjukkan bahwa Social Network Sites pada platform Facebook, Instagram, Twitter, Youtube sebagai alat untuk meningkatkan engagement stakeholder internal dan eksternal untuk mewujudkan terbangunnya hubungan, meningkatkan citra dan reputasi bagi perusahaan. Social Networking Sites berperan untuk mengukur matriks bagi stakeholder, menilai kinerja perusahaan, menilai partisipasi stakeholder, menilai strategi pemasaran, membangun hubungan relasional, hingga pembentukan loyalitas pelanggan. Aktivitas online yang dilakukan oleh pemangku kepentingan berhubungan dengan citra reputasi perusahaan sehingga harus dikelola dengan baik oleh humas digital dan komunikasi korporat.

Keywords: Social Network Sites, Stakeholder, Engagement, Digital Public Relations, Reputation.

\section{PENDAHULUAN}

Media sosial menciptakan alur informasi yang baru dalam proses komunikasi antar masyarakat jaringan dalam dunia virtual. Perkembangan teknologi digital berdampak besar pada proses komunikasi didalamnya. Adanya difusi internet, media digital telah mendorong perkembangan jaringan masyarakat secara horizontal dan proses yang berlangsung menjadi interaktif. Dengan konvergensi antara Internet dan nirkabel komunikasi dan difusi bertahap dari kapasitas broadband yang lebih besar, kekuatan komunikasi dan pemrosesan informasi dari Internet didistribusikan ke semua bidang kehidupan sosial. Digitalisasi komunikasi telah mendorong difusi teknologi dan sistem media yang terintegrasi secara resmi di mana produk dan proses dikembangkan beragam platform yang mendukung berbagai konten dan ekspresi media di dalamnya jaringan yang sama.

doi: https://doi.org/10.51544/jlmk.v5i2.2161

(C) 2021 Jurnal Lensa Mutiara Komunikasi. This is an open access article under the CC BY-SA license Website: http://e-journal.sari-mutiara.ac.id/index.php/JLMI

http://e-journal.sari-mutiara.ac.id 
Perkembangan media telah bertransformasi ke arah digital yang menawarkan portabilitas, interaktivitas dan mobilitas berupa kemampuan untuk menyediakan penerimaan bergerak tidak terbatas ruang dan waktu. memaparkan adanya perubahan konsep media terjadi seiring dengan perubahan peradaban manusia yang telah memasuki era masyarakat informasi. Setiap informasi yang dipublikasi oleh perusahaan menjadi sangat penting demi terwujudnya keselarasan antara identitas internal perusahaan dan citra eksternalnya. Untuk menciptakan citra dan reputasi yang positif bagi para pemangku kepentingan merupakan tujuan dari seluruh organisasi atau perusahaan. Reputasi juga berperan bagi organisasi terhadap keberlanjutan dan keberlangsungan usaha yang dijalankan. Cornelissen (2014) memaparkan bahwa citra (corporate image) adalah sekumpulan respons dari seseorang terhadap satu atau lebih pesan yang disampaikan oleh sebuah perusahaan pada suatu waktu. Lebih lanjut, reputasi perusahaan (corporate reputation) ialah representasi pengetahuan kolektif seorang individu terhadap reputasi perusahaan dari masa lalu hingga saat ini.

Departemen kehumasan dan korporat pada suatu organisasi atau perusahaan berperan dalam bidang peningkatan citra, pengelola reputasi juga menjaga stabilitas dengan seluruh stakeholder. Stakeholder internal meliputi pemangku kepentingan dari organisasi itu sendiri karyawan, pemilik, investor. Stakeholder eksternal meliputi consumer, customer atau pelanggan, media, supplier, pemetintah, kelompok masyarakat, komunitas, atau masyarakat secara umum. Pengelolaan stakeholder menjadi penting bagi keberlanjutan suatu organisasi. Diperlukan suatu strategi untuk dapat mengelola pengalaman dan keterlibatan stakeholder sehingga hubungan antara organisasi dapat tercipta dengan baik. Peran dan fungsi komunikasi dengan stakeholder dilakukan oleh departemen kehumasan yang memegang peran penting memiliki tanggung jawab untuk mengelola hubungan dengan stakeholder. Tidak hanya mengelola hubungan dengan para pemangku kepentingan, namun saat ini peran humas juga berorientasi pada peningkatan keterlibatan stakeholder pada organisasi atau perusahaan dalam rangka membangun hubungan jangka panjang sehingga sehingga perusahaan dapat melanggengkan reputasi yang baik.

Era digital memberikan keuntungan berupa kemudahan akses digital mempengaruhi pola konsumsi. Dalam bidang komunikasi korporat dan kehumasan, terjadinya revolusi industri menciptakan kemudahan bagi masyarakat. Adanya otomatisasi komputer pada tahun 1970-an komunikasi korporat dan kehumasan digunakan secara taktikal sebagai peran pendukung finance dan marketing. Perannya untuk mengumumkan pada khalayak mengenai keputusan perusahan, kegiatan, dan promosi produk dan jasa (Cornelissen, 2014). Otomatisasi dari komputer membantu proses komunikasi bidang kehumasan menjadi lebih mudah dan proses komunikasi menjadi menjadi terotomatisasi, lebih mudah, efisien dan efektif. Kemudian adanya perluasan jaringan dan digitalisasi melalui internet mengelevasi komunikasi korporat untuk membangun stakeholder secara dua arah. Digitalisasi membuat stakeholder lebih aktif dalam memberi pandangan terhadap organisasi, begitupun organisasi pada stakeholder. Coleman (2013) menjelaskan bahwa internet menjangkau, memperluas keterlibatan dalam kehidupan publik. Transparansi dan otentikasi perusahaan penting bagi stakeholder.

Perubahan sistem produksi memberikan keuntungan bagi pengguna yakni kegiatan yang dilakukan menjadi lebih mudah dan lebih efisien. Dalam perkembangan internet dalam bidang kehumasan juga memiliki dampak yang signifikan. Melalui internet komunikasi yang berlangsung menjadi lebih mudah terutama untuk membangun hubungan dengan stakeholder, menciptakan engagement dengan pelanggan, serta dapat memberikan informasi juga pengawasan informasi dalam rangka menjaga citra dan reputasi pada perusahaan. Selain itu, melalui media 
sosial juga terbangun ruang interaktif yang terjalin antara perusahaan dengan stakeholder sehingga tujuan dari organisasi dapat tercapai.

Adanya perkembangan Social Networking Sites memiliki peran penting dalam bidang komunikasi dan kehumasan dikarenakan dapat menjangkau khalayak yang banyak dengan tidak dibatasi ruang dan waktu. Dalam bidang kehumasan dan komunikasi korporat adanya Social Networking Sites membantu dalam membangun hubungan dengan stakeholder, menciptakan good stakeholder experience sehingga berpengaruh pada kepuasannya sehingga hal ini menjadi penting bagi perusahan dapat mengeksplorasi peran Social Networking Sites yang akan berujung pada terbentuknya citra dan reputasi perusahaan. Penelitian mengenai SNS seperti Facebook telah dilakukan oleh Ji, Y G., et al, (2016) hasil menunjukkan bahwa aktivitas online yang dilakukan oleh stakeholder berhubungan dengan reputasi online perusahaan. Hasil menunjukan diantara aktivitas keterlibatan stakeholder, indikator yang signifikan dari reputasi organisasi adalah adanya komentar positif dan negatif. Publik yang aktif menjadi sumber utama dalam pendistribusian informasi yang dibentuk oleh pengetahuan secara kolektif, dibagikan dan diakui oleh kelompok kepentingan yang lebih besar sehingga mempengaruhi reputasi perusahaan. Melalui SNS, nilai-nilai yang berhubungan dengan organisasi dapat diperluas dan menentukan besaran juga arah organisasi.

Pendekatan kualitatif digunakan dalam penelitian melalui kajian literatur untuk mengeksplorasi lebih mendalam mengenai bagaimana peran Social Networking Sites dalam bidang kehumasan dan komunikasi korporat untuk meningkatkan stakeholder engagement. Adanya perkembangan Social Networking Sites yang didalamnya terdapat transformasi baru dalam bidang humas menjadi salah satu hal yang penting untuk ditelaah lebih lanjut, diharapkan penulisan ini dapat memberikan signifikansi dan rekomendasi secara akademis dalam menjelaskan perkembangan Social Networking Sites yang berorientasi pada proses membangun relasi dan peningkatan keterlibatan stakeholder pada citra dan reputasi perusahaan.

\section{TINJAUAN LITERATUR}

\section{Transformasi Komunikasi Korporat dan Kehumasan di Era Digital}

Komunikasi korporat memerlukan pengelolaan secara strategis sebagai panduan organisasi dalam berkomunikasi dengan stakeholder. Komunikasi korporat didefinisikan sebagai fungsi manajemen yang bertanggung jawab untuk melakukan pengawasan, koordinasikan pekerjaan yang dilakukan praktisi komunikasi. Level fungsi manajemen dari komunikasi korporat tidak hanya pada internal namun juga eksternal demi menciptakan komunikasi yang efektif (Cornelissen, 2014).

Adanya komunikasi korporat berfungsi untuk menjaga, membangun, meningkatkan reputasi yang baik pada pemangku kepentingan mengenai perusahaan. Komunikasi korporat merupakan instrumen manajerial dimana seluruh komunikasi dikoordinasikan, diharmonisasikan dengan efisien agar tercipta hubungan yang saling menguntungkan dengan perusahaan. Komunikasi korporat memiliki tugas untuk memotivasi, persuasi, kepada karyawan, customer, publik sehingga tercipta hubungan yang menguntungkan satu dengan lainnya (Cornelissen, 2014).

Reputasi adalah cara perusahaan dipersepsikan, berdasarkan pesan dan suatu hal pada titik waktu tertentu. Sekumpulan makna yang disimpulkan oleh individu dan tanggapan terhadap satu atau lebih sinyal tentang organisasi pada satu titik waktu tertentu (Cornelissen, 2014). Mengelola citra penting bagi perusahaan karena citra yang positif mendorong terbentuknya kesan atau persepsi yang positif bagi stakeholder yang menguntungkan bagi perusahaan. 
Corporate Reputation merupakan representasi dari pengetahuan kolektif seorang individu terhadap reputasi perusahaan dari masa lalu hingga saat ini (Cornelissen, 2014). Untuk mengelola reputasi perusahaan sangat penting bagi organisasi dalam mencapai keselarasan atau transparansi antara identitas internal dan citra eksternalnya.

Stakeholder didefinisikan sebagai individu maupun kelompok yang memiliki pengaruh dan dipengaruhi dalam pencapaian tujuan organisasi. Peran kehumasan dan komunikasi korporat tidak hanya mengelola hubungan dengan para pemangku kepentingan, namun saat ini peran humas juga berorientasi pada peningkatan keterlibatan stakeholder pada organisasi atau perusahaan dalam rangka membangun hubungan jangka panjang sehingga sehingga perusahaan dapat melanggengkan reputasi yang baik. Terdapat pendekatan mengenai stakeholder yaitu stakeholder management dan stakeholder engagement. Manajemen stakeholders merupakan pendekatan yang berfokus pada bagiamana cara mengelola hubungan dengan pemangku kepentingan yang berorientasi pada tujuan jangka pendek. Proses komunikasi yang berlangsung memiliki sifat model komunikasi asimetris dua arah atau model komunikasi simetris satu arah. Sedangkan stakeholder engagement fokus pada keterlibatan pemangku kepentingan pada perusahaan atau organisasi yang berorientasi pada tujuan jangka panjang. Proses komunikasi yang berlangsung memiliki sifat model komunikasi simetris dua arah dialog dan konsultasi. Pada keterlibatan stakeholder, peran kehumasan menekankan kolaborasi sehingga saling menguntungkan dengan sistem Cornelissen (2014).

Hubungan masyarakat atau public relation merupakan istilah dari sebuah industri komunikasi yang telah mendunia yang berhubungan dengan organisasi dan publik. Ditinjau dalam konteks historis, perkembangan komunikasi korporat mengalami evolusi. Cornelissen (2014) menjelaskan pada tahun 1970 komunikasi korporat terfragmentasi, digunakan secara taktikal sebagai peran pendukung finance dan marketing. Perannya untuk mengumumkan pada khalayak mengenai keputusan perusahan, kegiatan, dan promosi produk dan jasa. Pada tahun 1980 komunikasi korporat lebih bersifat strategis untuk membangun reputasi perusahaan. Terdapat integrasi antar departemen sebelumnya (sales, media relations, advertising, promotions). Terdapat prosedur komunikasi, mekanisme koordinasi, komunikasi organisasi secara keseluruhan. Lebih lanjut, pada tahun 1990 komunikasi korporat fokus berorientasi pada reputasi, identitas, dan branding perusahaan merupakan sesuatu yang penting bagi stakeholder terhadap perusahaan. Komunikasi yang berlangsung dalam organisasi bersifat linear, satu arah dan stakeholder dapat dikontrol. Pada era new media (2000), mengatur dan mengontrol stakeholder sudah tidak relevan. Stakeholder lebih aktif dalam memberi pandangan terhadap organisasi. Transparansi dan otentikasi perusahaan penting bagi stakeholder.

Penelitian mengenai peran Public Relation bagi organisasi pemerintahan dilakukan oleh Ginting \& Rahmalinda (2018) yang menunjukkan bahwa Public Relation berperan dalam meningkatkan citra positif dan berupaya dalam menangani permasalahan yang terjadi. Lebih lanjut, kampanye serta pesan yang dilakukan oleh Public Relation juga dapat membentuk sikap positif bagi khalayak (Ginting \& Simamora, 2018). Pentingnya citra dan reputasi perusahaan menjadi aspek vital dalam keberlanjutan roda perusahaan. Penelitian yang dilakukan oleh (Sugianto \& Sembiring, 2018) menunjukan pada salah satu perusahan FMCG Coca-Cola Amatil Indonesia di Kecamatan Medan Labuhan Kota Medan. Perusahaan telah berhasil membangun citra positif yang dilihat dari ketiga indikator yakni persepsi, kognisi, motivasi dan sikap. Perusahaan dapat menjaga, memberdayakan dan peduli terhadap masyarakat sekitar. 


\section{Perkembangan Social Networking Sites}

Bentuk baru masyarakat yang dikonseptualisasikan adanya perubahan historis, membentuk jaringan yang terdiri dari konfigurasi lokal, nasional dan global dalam ruang multidimensi interaksi sosial. Jaringan didefinisikan sebagai struktur komunikasi kompleks, yang dibangun atau dibuat pada serangkaian tujuan secara bersamaan yang memperhatikan kesatuan tujuan dan fleksibilitas pelaksanaan dengan kemampuan adaptasi terhadap lingkungan (Castells, 2009).

Castells (2009) menjelaskan konsep masyarakat jaringan sebagai masyarakat yang struktur sosialnya dibuat di sekitar jaringan, yang diaktifkan oleh informasi dimana didalamnya diproses secara digital berbasis teknologi informasi dan mikroelektronik. Pada masyarakat jaringan, globalisasi yang berlangsung tidak merata, kenyataannya ciri penting dari struktur sosial sangat tinggi. Masyarakat jaringan sebagai arsitektur global dan hasil dari interaksi antara berbagai geografi dan geometri dari jaringan dan sebagai hasil dari tatanan interaksi antara geometri dan jaringan dominan.

Social Networking Sites memberi kemudahan dalam kehidupan sehari-hari yang dapat menghubungkan individu-individu dengan teknologi dan fitur yang beragam. Social Networking Sites merupakan layanan dengan basis web yang memungkinkan seseorang untuk membangun profil baik publik maupun semi publik dalam suatu sistem. SNS juga dapat artikulasikan daftar pengguna yang memiliki koneksi serta dapat melintasi juga melihat daftar koneksi yang dimiliki atau melihat orang lain dalam sistem (Boyd, 2008). SNS berkembang pada akhir 1990-an dimana banyak situs yang mengembangkan banyak iklan menggunakan fitur canggih bagi pengguna untuk menemukan dan mengelola teman. Permulaan SNS dengan kemunculan Friendster pada tahun 2002 yang menjadi arus utama internet yang menjadi situs untuk memperkenalkan orang asing, serta dirancang untuk membantu orang-orang untuk bertemu (Liu \& Ying, 2010).

Berlanjut pada tahun 2003 juga muncul situs profesional seperti LinkedIn, Flick untuk berbagi foto, Last FM untuk berbagi musik dan Youtube untuk berbagi video. Kemudian kemunculan MySpace menciptakan keunikan melalui fitur yang diciptakan dengan memfasilitasi pengguna membuat profil sesuai dengan preferensi dan keinginanya. Kemudian Facebook juga dirancang untuk berekspansi menyasar jaringan pendidikan seperti perguruan tinggi. Pengguna Facebook dapat memungkinkan pengguna mempersonalisasi profil yang dimiliki yang sifatnya personal seperti preferensi buku, film favorit sehingga pada perjalanannya Facebook menjadi situs web terbesar di Amerika pada tahun 2010 (Liu \& Ying, 2010)

Adapun terdapat tren yang terjadi pada Social Networking Sites. Pertama, terdapat konsep real time dan location based. Real time memungkinkan pengguna dapat membuat dan mempublikasikan konten dalam waktu yang sama. Seperti twitter yang dapat memungkinkan individu untuk publikasi tweet secara langsung atau facebook dapat memberikan umpan langsung pada kontennya. Kedua, adalah penggunaan Social Networking Sites dalam dunia bisnis seperti penggunaan Facebook dan Twitter dalam membangun brand image suatu perusahaan. Terdapat lima hal kegunaan SNS dalam suatu bisnis yang terdiri dari: menciptakan brand awareness, alat membangun reputasi secara online, berfungsi dalam proses perekrutan, ruang belajar teknologi dalam memahami kompetitor, serta alat untuk melihat prospek. Perusahaan dapat menggunakan SNS untuk mendorong keterlibatan konsumen dalam rangka meningkatkan produk atau layanan yang mereka miliki. Ketiga, adalah untuk penggunaan komunitas sosial. Seperti SNS digunakan untuk memfasilitasi komunikasi antara guru dan murid. Selain itu, para mahasiswa juga menggunakan SNS sebagai ruang untuk membentuk jaringan 
dimana mereka dapat mengetahui informasi seputar dunia magang dan pekerjaan (Liu \& Ying, 2010).

Social Networking Sites menyediakan sumber dapa pengguna yang dikumpulkan melalui profil melalui otomatisasi maupun data yang disediakan langsung dari perusahaan. Hal ini memungkinkan pihak lain untuk melakukan analisis jaringan dengan eksplorasi pola hubungan pertemanan jaringan berskala besar, penggunaan dan analisis tren pada SNS yang digunakan. SNS mendukung hubungan sosial yang sudah ada, sehingga memungkinkan individu untuk memiliki keterhubungan satu sama lain dan terintegrasi dalam kehidupan sehari-hari bagi pengguna bahkan SNS juga berperan sebagai ruang sosialisasi dalam jaringan publik (Boyd, 2008). Hasil penelitian menunjukkan bahwa penggunaan Social Networking Sites contohnya Facebook sebagai alat dengan potensi yang tinggi yang dapat digunakan untuk menilai kinerja perusahaan, menilai partisipasi pemangku kepentingan, menilai strategi pemasaran di Facebook, menilai strategi komunikasi, dan reputasi perusahaan secara online baik (Bonson \& Ratkai, 2012).

\section{Peran Social Networking Sites pada Komunikasi Korporasi dan Kehumasan}

Revolusi Industri 4.0 memanfaatkan sistem produksi yang telah menggunakan komputer yang diperluas dengan adanya koneksi jaringan dan digitalisasi melalui internet. Adanya perubahan sistem produksi memberikan keuntungan bagi pengguna yakni kegiatan yang dilakukan menjadi lebih mudah dan lebih efisien. Dalam perkembangan internet dalam bidang kehumasan juga memiliki dampak yang signifikan. Melalui internet komunikasi yang berlangsung menjadi lebih mudah terutama untuk membangun hubungan dengan stakeholder, menciptakan engagement dengan pelanggan, serta dapat memberikan informasi juga pengawasan informasi dalam rangka menjaga citra dan reputasi pada perusahaan. Strategi komunikasi diperlukan untuk membangun kehadiran aktif pada SNS untuk meningkatkan keuntungan perusahaan, mencegah krisis citra perusahaan, hingga membangun kepercayaan bagi para pemangku kepentingan. Berdasarkan penelitian yang dilakukan oleh (Mamic \& Almaraz, 2013) dengan menggunakan metode analisis isi pada SNS Twitter di 14 perusahaan. Hasil penelitian menunjukkan perusahaan menggunakan SNS twitter sebagai alat komunikasi satu arah dan mengabaikan potensi interaktivitas dan stakeholder engagement. Diperlukan upaya dari komunikasi korporat dan kehumasan untuk dapat melihat SNS sebagai alat yang potensial untuk dapat mengembangkan interaktivitas bagi penggunanya.

Komunikasi korporat dan kehumasan berperan dalam proses manajemen informasi yang berlangsung ke publik. Seiring dengan perkembangan teknologi, sumberdaya manusia harus memiliki kapabilitas, keahlian dalam menganalisis dan menggunakan SNS. Selain itu, dalam pembentukan opini publik juga berlangsung dengan cepat dan mudah dengan adanya media sosial sehingga kehumasan juga berperan untuk mengidentifimasi publik yang potensial menjadi influencer. Akan muncul ruang publik yang memfasilitasi pertukaran informasi tanpa batas. Media sosial yang digunakan oleh komunikasi korporat harus dapat diukur melalui evaluasi efektivitas program komunikasi yang dilakukan. Penggunaan SNS dimanfaatkan untuk menjangkau pemangku kepentingan baik internal maupun eksternal (Purwandini \& Irwansyah, 2018). 


\section{METODE PENELITIAN}

Metode yang digunakan dalam penelitian ini adalah Literature Review. Literature Review merupakan pencarian literatur yang berhubungan dengan sebuah topik. Literature review digunakan untuk menelaah secara kritis penelitian yang berkaitan dengan fenomena yang menarik dan ide-ide teoritis yang relevan Bryman (2012). Pengumpulan artikel jurnal diperoleh penulis berdasarkan sumber informasi terkait konteks Social Network Sites, Stakeholder, Engagement, Digital Public Relations, Reputation. Terdapat lima tahapan dalam proses pemilihan literatur hingga kesimpulan yang terdiri dari proses pemilihan literatur, pengembangan kriteria, identifikasi, mensintesis dan menganalisis informasi, serta membuat kesimpulan (Neuman, 2014). Pemilihan literatur berdasarkan dibatasi topik tertentu: penulis memberikan ruang lingkup batasan kriteria yakni artikel yang diterbitkan pada lingkup Social Network Sites, Stakeholder, Engagement, Digital Public Relations, Reputation. Pada proses identifikasi, peneliti menemukan delapan artikel jurnal, kemudian artikel tersebut dianalisis dan mengelaborasi konsep yang ada pada tinjauan teoritis yang mengelaborasi mengenai bagaimana peran Social Networking Sites dalam bidang kehumasan dan komunikasi korporat untuk meningkatkan stakeholder engagement. Membuat kesimpulan: peneliti membuat kesimpulan berdasarkan hasil elaborasi konsep yang sebelumnya dipaparkan sesuai dengan konteks dan fenomena pada jurnal.

\section{HASIL DAN PEMBAHASAN}

Pada bagian hasil akan dijelaskan mengenai temuan penulis dalam jurnal ilmiah yang merujuk pada kerangka konseptual Social Networking Sites dalam bidang kehumasan dan komunikasi korporat untuk meningkatkan stakeholder engagement

Data

yang dikumpulkan dalam tabel/gambar harus dilengkapi teks naratif dan disajikan dalam bentuk yang mudah dimengerti. Jangan ulangi secara panjang lebar data yang telah disajikan dalam tabel dan gambar. Berikut contoh tabel:

Tabel 1

Hasil Telaah Literatur

\begin{tabular}{|c|c|c|c|}
\hline No & $\begin{array}{l}\text { Judul dan Nama } \\
\text { Peneliti }\end{array}$ & Metode dan Hasil Penelitian & $\begin{array}{l}\text { Peran Social } \\
\text { Networking Sites pada } \\
\quad \text { Stakeholder } \\
\text { Engagement }\end{array}$ \\
\hline 1 & $\begin{array}{l}\text { A set of metrics to } \\
\text { assess stakeholder } \\
\text { engagement and } \\
\text { social legitimacy on } \\
\text { a corporate } \\
\text { Facebook page }\end{array}$ & 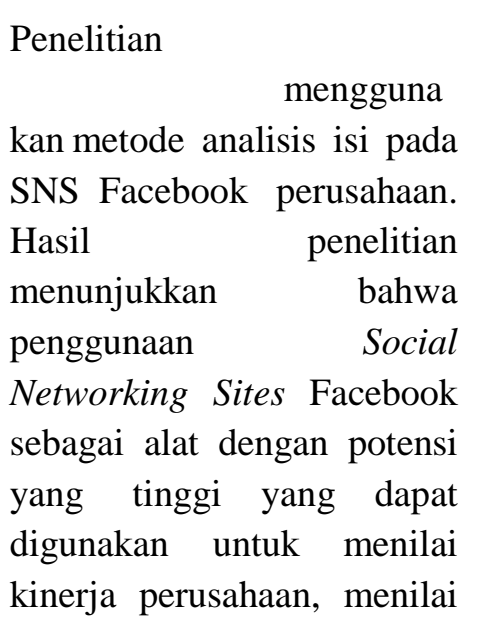 & $\begin{array}{l}\text { Saluran Social Networking } \\
\text { Sites Facebook Facebook } \\
\text { yang dimiliki perusahaan } \\
\text { dapat mengukur matriks } \\
\text { dari sisi pemangku } \\
\text { kepentingan yang terdiri } \\
\text { dari tiga kategori. } \\
\text { Pertama, pengukuran } \\
\text { reaktivitas, dialog dan } \\
\text { stakeholder engagement } \\
\text { melihat nilai dari umpan } \\
\text { balik yang dilakukan oleh }\end{array}$ \\
\hline
\end{tabular}


Staking

reputationon
stakeholders
How does
Stakeholders'
Facebook
engagement helps
or ruins a
company's
reputation?

(Ji, Y G., et al., 2016) partisipasi pemangku

kepentingan, menilai strategi pemasaran di Facebook, menilai strategi komunikasi, dan reputasi perusahaan secara online baik produk maupun layanan.

\section{Penelitian}

kan metode analisis isi berdasarkan data longitudinal selama 5 tahun. Hasil menunjukan diantara aktivitas keterlibatan stakeholder, indikator yang signifikan dari reputasi organisasi adalah adanya komentar positif dan negatif. Adanya komentar positif akan berdampak positif bagi perusahaan.

Sebaliknya , komentar negatif akan membawa pengaruh negatifpada perusahaan. para pemangku kepentingan berdasarkan penggunaan fitur likes, berbagi, dan komentar pada postingan. Kedua, social legitimacy dan voluntary disclosure dilihat dari analisis konten diketahui postingan pada konten CSR, pemasaran dan penjualan, layanan pelanggan dan kategori lainnya. Ketiga, pada poin stakeholder moods yang dilihat secara kualitatif pada umpan balik para pemangku kepentingan baik yang bersifat positif maupun negatif.

Penggunaan SNS

Facebook meliputi aktivitas online yang dilakukan oleh stakeholder dengan reputasi online perusahaan melalui indikator yang menjelaskan interaksi keterlibatan pemangku kepentingan dengan perusahaan yang terdiri dari: jumlah like, share, komentar negatif, komentar positif, dan komentar netral. Hasil menunjukan diantara aktivitas keterlibatan stakeholder, indikator yang signifikan dari reputasi organisasi adalah adanya komentar positif dan negatif. Publik yang aktif menjadi sumber utama dalam pendistribusian informasi yang dibentuk oleh pengetahuan secara kolektif, dibagikan dan diakui oleh kelompok kepentingan yang lebih besar sehingga 
3

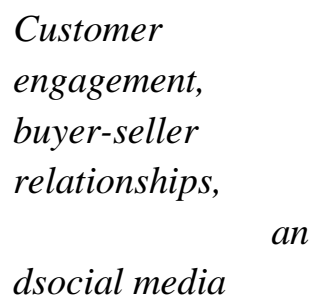

(Sashi, A., 2012)
Penelitian

kanmetode literature review.

Hasil menunjukkan

dalam

membentuk

keterliba

tan pelanggan terdapat siklus yang mengalami transformasi yang terdiri dari unsur koneksi, interaksi, kepuasan, retensi,loyalitas.

Penelitian

mengguna

corporations

engage with

stakeholders

through Twitter

(Mamic \& Almaraz, 2013) mempengaruhi reputasi perusahaan. Melalui SNS, nilai-nilai yang berhubungan dengan organisasi dapat diperluas dan menentukan besaran juga arah organisasi.

Adanya SNS berperan dalam membangun koneksi, hubungan relasional antara pelanggan dengan penjual adalah mereka harus terhubung satu sama lain dan menjangkau pelanggan yang lebih banyak.

Penggunaan Social

Networking Sites twitter pada 14 perusahaan tidak menerapkan potensi interaktivitas untuk membangun stakeholder engagement. Diketahui bahwa tweet dan retweet yang digunakan memiliki kuantitas yang kecil. Kemudian penggunaan hyperlink dan hashtag juga ditemui bahwa hampir sepertiga perusahaan melakukan tweet berisi hyperlink yang tidak berhubungan langsung dengan perusahan.

Sedangkan strategi komunikasi diperlukan untuk membangun kehadiran aktif pada SNS untuk meningkatkan keuntungan perusahaan, mencegah krisis citra perusahaan, hingga membangun kepercayaan bagi para pemangku kepentingan. 


Measuring social
media influencer
index insights from
facebook, Twitter
and Instagram

Penelitian

mengguna

kan metode survei. Hasil

menunjukan

bahwa

engagement, penjangkauan

(Arora, A., et al., 2019)

Pengaruh Customer

Engagement

Melalui

Medi

a

Sosial

terhada

pKepercayaan

Merek

(Mahayani, C.O., et

al. 2019) penelitian menunjukan bahwa SNS berperan dapat meningkatkan keterlibatan pelanggan dan berpengaruh signifikan terhadap kepercayaan brand Shopee.
Penelitian ini

mengidentifikasi indeks

influencer di seluruh

platform media sosial

Twitter, Instagram,

Facebook. SNS

membentuk cara interaksi

yang baru dalam proses

komunikasi dan

keterlibatan termasuk para pemangku kepentingan.

Masing-masing fitur pada platform diukur

berdasarkan overall

footprint, kecepatan

engagement per jam dan

harian, engagement

outreach, sentimen audiens

serta posting rate. Hasil

menunjukan bahwa

engagement, penjangkauan

sentimen serta

pertumbuhan menjadi

peran kunci dan dapat

dijadikan pertimbangan

untuk menentukan dan

identifikasi mengenai

keterlibatan penjangkauan

yang lebih besar yang dapat digunakan berbagai aspek, mulai dari manajemen komunikasi, pemasaran di media sosial hingga e-commerce.

Pengaruh signifikan mengguna dihasilkan dari tigavariabel kan metode survei. Hasil pada kepercayaan merk

Shopee di media sosial. Pertama adalah variabel brand connection, merupakan hubungan personal yang terbangun antara customer dengan merk brand Shopee. Variabel kedua adalah contingency interactivity yang meliputi kegiatan atau aktivitas konsumen dalam melakukan interaksi 
Measuring YouTube

Channel Subscriber

Loyalty: The Role of

Quality, Corporate

Image and Viewer

Satisfaction.

(Maulana, et al,

2020)

Instagram
Sentiment Analysis
with Naive Bayes
and KNN:
Exploring Customer
Satisfaction

f Digital

Payment

Services

Indonesia.

(Sudira, H., et al., 2019).
Penelitian

mengguna

kanmetode survei. Penelitian

menunjukan terdapat hasil

yang signifikan antara

kualitas konten dengan citra dankepuasan

pelanggan.

Kemudian, kepuasan

pelanggan berpengaruh positifpada

loyalitas pelanggan.

seperti memberikan like, komen, repost dan share dalam instagram Shopee. Variabel terakhir adalah company attitude yakni kemampuan perusahaan untuk menunjukan sikap baik seperti mempublikasikan stabilitas finansial sehingga dapat bersaing dengan kompetitor.

Penggunaan Youtube dapat berpengaruh pada citra dan kepuasan pelanggan. Konten dan kualitas dari produk yang dipublikasi serta tercerminnya citra positif dari perusahaan mendorong terciptanya citra positif dan kepuasan pelanggan. Adanya kepuasan pelanggan kemudian memicu pembentukan loyalitas atas adanya sikap, perilaku yang berkelanjutan.

Tingkat kepuasan pembayaran digital di Indonesia pada di Instagram dilihat melalui sentimen yang dianalisis pada SNS Instagram menggunakan datamining. Go-Pay menjadi penyedia layanan dengan kualitas layanan direpresentasikan dengan adanya komentar yang positif. Kemudian pada penyedia layanan lainnya yakni LinkAja dan OVO cenderung memiliki sentimen yang netral. Implikasi praktis bagi kehumasan adalah bahwa dalam membangun strategi komunikasi dengan stakeholder pada instagram 


\begin{abstract}
dan media sosial lainnya harus dapat melebur secara taktis agar sentimen negatif yang berhubungan dengan perusahaan dapat diatasi dengan baik dan citra perusahaan dapat terbangun secara positif.
\end{abstract}

Sumber: Diolah oleh penulis 2021

Diskusi penelitian ini membahas hasil studi kasus jurnal terdahulu dengan konteks Peran Social Networking Sites dalam bidang kehumasan dan komunikasi korporat untuk meningkatkan stakeholder engagement. Telaah pertama pada Bonson \& Ratkai (2013) penelitian yang berjudul A set of metrics to assess stakeholder engagement and social legitimacy on a corporate Facebook page. Social Networking Sites pada perusahaan digunakan untuk berkomunikasi dengan pemangku kepentingan seperti bagaimana perusahaan dapat mengetahui brand mereka. Penelitian ini menganalisis bagaimana pengaruh saluran SNS online yaitu Facebook yang dimiliki perusahaan dapat mengukur matriks dari sisi pemangku kepentingan yang terdiri dari tiga kategori yaitu 1) reaktivitas, dialog dan stakeholder engagement; 2) social legitimacy dan voluntary disclosure; 3) stakeholder moods. Penelitian ini tidak hanya mengeksplorasi bagaimana cara mengukur matriks penggunaan Facebook bagi para pemangku kepentingan, namun juga membantu para peneliti untuk mengidentifikasi cara menggunakan Facebook untuk manajemen reputasi online. Adapun penelitian yang dilakukan berfungsi untuk menjawab reaktivitas komunikasi yang dialogis berlangsung pada Facebook perusahaan, pengukuran keterlibatan para pemangku, suasana hati pemangku kepentingan pada Facebook perusahaan; serta pengukuran legitimasi sosial para pemangku kepentingan.

Teori dan konsep yang dijelaskan pada penelitian bahwa adanya social presence dari perusahaan dapat difasilitasi oleh SNS yang memungkinkan terbangunnya komunikasi simetris bagi para pemangku kepentingan. Perusahaan berperan untuk memfasilitasi berlangsungnya proses komunikasi yang dialogis dan simetris dari pemangku kepentingan dan tidak boleh didominasi oleh satu pihak. Harus ada proses komunikasi yang kooperatif. Dalam konteks ini, teknologi internet berperan untuk menjangkau kelompok dari seluruh komunitas. Berdasarkan perspektif dari para pemangku kepentingan, perusahaan harus mencapai tujuan yang sesuai dengan kepentingan stakeholder. Pada pengukuran reaktivitas, dialog dan stakeholder engagement melihat nilai dari umpan balik yang dilakukan oleh para pemangku kepentingan. Terdapat tiga matriks yang mengukur kuantitas umpan balik dari pemangku kepentingan yakni komitmen, popularitas dan viralitas. Penelitian ini mengukur viralitas untuk melihat keefektifan pesan pada Facebook yang dilihat berdasarkan penggunaan tombol "berbagi" di Facebook. Berdasarkan analisis yang dilakukan, dari sepuluh perusahaan yang dianalisis, sebanyak $93 \%$ postingan pada "wall" atau dinding disukai, 61\% dikomentari dan 34\% dibagikan. Rata-rata jumlah likes per postingan konten sebanyak lebih dari 1500 dan postingan komentar 123, sedangkan rata-rata jumlah konten yang dibagikan sebanyak 29.

Pada poin social legitimacy dan voluntary disclosure berdasarkan analisis konten diketahui postingan pada konten Facebook 35\% terkait dengan Corporate Social Responsibility yang diharapkan dapat membantu mendapatkan legitimasi sosial. Konten lainnya adalah 
pemasaran dan penjualan dengan rasio tertinggi yaitu $41 \%$, layanan pelanggan sebesar $3 \%$ dan kategori lainnya sebanyak $21 \%$. Lebih lanjut pada poin stakeholder moods bahwa umpan balik yang berasal percakapan berupa komentar yang terinput di Facebook. Percakapan negatif juga merupakan representasi dari umpan balik pada SNS, hasil menunjukan bahwa perusahaan tidak memiliki ketakutan untuk konfirmasikan umpan balik yang sifatnya negatif dan jumlah rata-rata hanya $7 \%$ komentar yang bersifat negatif, 93\% bersifat positif. Berdasarkan hasil penelitian diketahui bahwa SNS merupakan

alat dengan potensi yang tinggi yang dapat digunakan untuk menilai kinerja perusahaan, menilai partisipasi pemangku kepentingan, menilai strategi pemasaran di Facebook, menilai strategi komunikasi, dan reputasi perusahaan secara online baik produk maupun layanan.

Pada penelitian Staking reputation on stakeholders: How does stakeholders' Facebook engagement help or ruin a company's reputation Ji, Y G., et al. (2016) mengeksplorasi hubungan antara aktivitas online yang dilakukan oleh stakeholder dengan reputasi online perusahaan. Data dikumpulkan dari tahun 2009 hingga 2013, perusahaan Fortune 500 di facebook. Terdapat lima indikator yang menjelaskan interaksi keterlibatan pemangku kepentingan dengan perusahaan yang terdiri dari: jumlah like, share, komentar negatif, komentar positif, dan komentar netral. Hasil penelitian menunjukkan bahwa diantara aktivitas keterlibatan stakeholder, indikator yang signifikan dari reputasi organisasi adalah adanya komentar positif dan negatif. Adanya komentar positif akan berdampak positif bagi perusahaan. Sebaliknya, komentar negatif akan membawa pengaruh negatif pada perusahaan. Implikasi praktis dalam penelitian yang dilakukan adalah adanya perilaku aktif yang dilakukan pemangku kepentingan secara signifikan mempengaruhi hubungan mereka dengan organisasi dan evaluasi terhadap reputasi organisasi itu sendiri. Publik yang aktif menjadi sumber utama dalam pendistribusian informasi yang dibentuk oleh pengetahuan secara kolektif, dibagikan dan diakui oleh kelompok kepentingan yang lebih besar sehingga mempengaruhi reputasi perusahaan. Melalui SNS, nilainilai yang berhubungan dengan organisasi dapat diperluas dan menentukan besaran juga arah tentang bagaimana publik mampu memahami dan mengevaluasi suatu organisasi. Untuk itu, para pemangku kepentingan yang berperilaku aktif dalam organisasi melalui SNS dapat diprioritaskan oleh praktisi kehumasan. Sifat partisipatif dari kehadiran SNS dapat menawarkan pembangunan hubungan organisasi sehingga proses komunikasi berlangsung secara efisien dan transparan.

Pada saat yang bersamaan, individu dapat menggunakan SNS untuk berkumpul, bercerita, berbagi, mengeluh yang juga akan menyebabkan kerusakan reputasi perusahaan apabila tidak dipahami dan ditanggapi secara baik dan cepat. Untuk itu, diperlukan suatu strategi yang aktif untuk membangun citra dan reputasi perusahaan secara positif melalui SNS. Hal tersebut dapat dilakukan dengan mengidentifikasi pemangku kepentingan untuk melihat hubungan perilaku yang terjalin sehingga terdapat penyebaran informasi positif maka kehumasan dapat memanfaatkannya dan menjadikan aset bagi keuntungan perusahaan. Sebaliknya, apabila terdapat informasi negatif maka harus ditanggapi agar penyebaran informasi tidak berpotensi merusak reputasi perusahaan itu sendiri. Penelitian ini menjadi bukti empiris bahwa penggambaran hubungan antara pemangku kepentingan dan persepsi kognitif yang dilakukan dalam aktivitas online yang dilakukan memiliki peran penting dalam manajemen komunikasi dan kehumasan. Komunikasi online yang berlangsung pada SNS menjadi alat bagi kehumasan untuk mengamati secara real time interaksi antara pemangku kepentingan dengan organisasi. 
Penelitian yang berjudul Customer engagement, buyer-seller relationships, and social media yang dilakukan oleh Sashi (2012) mengeksplorasi model siklus keterlibatan pelanggan yang terdiri dari tujuh unsur koneksi, interaksi, kepuasan, retensi, loyalitas, advokasi dengan adanya perkembangan Social Networking Sites. Pada siklus pertama yaitu koneksi dimana untuk membangun hubungan relasional antara pelanggan dengan penjual adalah mereka harus terhubung satu sama lain terlebih dahulu. Untuk memanfaatkan koneksi, dapat menggunakan media sosial agar dapat menjangkau pelanggan yang lebih banyak. Media sosial mempermudah pembentukan hubungan antara pelanggan dengan perusahaan. Setelah tercipta hubungan (koneksi) antara pembeli, penjual dan perusahaan maka proses selanjutnya adalah interaksi. Sebelum adanya internet, interaksi yang dilakukan oleh pembeli dan pelanggan secara langsung, melalui surat, telepon atau kerabat. Namun, dengan perkembangan internet tidak terbatasi ruang dan waktu dan dapat menghubungkan orang-orang dari berbagai berlahan dunia. Adanya sms, email, virtual membuat interaksi berlangsung lebih cepat, lebih sering, lebih efisien dan efektif. Apabila interaksi telah tercipta, selanjutnya kepuasan dapat diciptakan. Adanya tingkat kepuasan yang tinggi dicapai ketika harapan pelanggan terlampaui dan emosi menjadi sangat positif tidak hanya digambarkan sebagai kepuasan tetapi kegembiraan (Oliver et al., dalam Sashi, 2012). Apabila perusahaan dapat menciptakan kepuasan pelanggan, maka retensi pelanggan dapat dihasilkan. Proses selanjutnya adalah komitmen. Komitmen kalkulatif lebih dari itu rasional dan hasil dari kurangnya pilihan atau biaya pengalihan. Komitmen kalkulatif mengarah pada tingkat loyalitas dan ketahanan pelanggan yang lebih tinggi hubungan dengan penjual. Adanya komitmen afektif sifatnya lebih emosional yang berasal dari hubungan timbal balik. Lebih lanjut, penelitian ini juga membahas mengenai matriks keterlibatan pelanggan yang terdiri dari pelanggan transaksional apabila pertukaran relasional rendah dan ikatan emosional rendah, pelanggan senang apabila pertukaran relasional rendah tetapi ikatan emosional tinggi, pelanggan setia apabila pertukaran relasional tinggi dan ikatan emosional rendah, serta pelanggan setia apabila pertukaran relasional tinggi dan ikatan emosional tinggi.

Implikasi manajerial berdasarkan penelitian bahwa dengan adanya perkembangan teknologi informasi dan internet mendukung terbentuknya media sosial. Dalam konteks pembeli dan penuual terjadi perubahan peran dimana pelanggan memungkinkan berpartisipasi lebih aktif dan terjalinnya interaksi yang lebih intens antara pembeli dan penjual sehingga terciptanya rasa penghargaan bersama. Dalam media sosial, pengambilan keputusan tidak hanya terpusat pada penjual namun saat ini bertransformasi pada partisipasi dan pengambilan keputusan pembeli. Media sosial menciptkaan kesempatan bagi pelanggan dan bukan pelanggan sehingga diharapkan bisa mempengaruhi orang lain dalam jejaring sosial mereka. Konten yang dibuat oleh organisasi pada media sosial dapat meningkatkan loyalitas, kepuasan pelanggan. Adanya keterlibatan pelanggan dapat mengelevasi pelanggan menjadi penggemar yang memungkinkan antar penggemar terhubung satu sama lainnya untuk meningkatkan kepuasan dan timbal balik.

Penelitian mengeksplorasi mengenai pemanfaatan twitter pada perusahaan untuk membangun keterlibatan dengan para pemangku kepentingan yang dilakukan oleh Mamic \& Almaraz (2013) pada penggunaan Twitter bagi perusahaan besar. Pada level organisasi, Social Networking Sites digunakan perusahaan untuk memungkinkan komunikasi dengan publik. Adanya SNS memungkinkan organisasi dapat melakukan interaksi dengan pengguna, dan dapat melihat feedback dari pengguna mengenai brand secara langsung. Dalam komunikasi secara online, SNS berfungsi sebagai fasilitas dalam pendekatan dialog yang berorientasi pada peningkatan interaktivitas perusahaan dengan stakeholder. 
Twitter menggunakan pertukaran yang koheren melalui fitur dengan simbol ‘@' individu dapat berinteraksi. Selain itu, individu dapat mengikuti orang lain (following) atau dapat diikuti oleh orang lain (followers). Adanya perilaku membentuk jejaring ini memungkinkan timbulnya hubungan timbal balik antar pengguna twitter. Melalui fitur public message dan retweets memungkinkan perusahaan untuk berkomunikasi dengan stakeholder leca terbuka, santai dan langsung. Melalui public message, pengguna dapat berkomentar dan mengajukan pertanyaan kepada organisasi. Melalui pesan-pesan tersebut, perusahaan dan pengguna dapat membentuk dialog yang dapat dilihat secara bersama. Kemudian melalui Retweet pengguna dapat memposting ulang dengan pengguna lain, dan dalam hal ini perusahaan juga dapat berbagi informasi dengan mengirimkan Retweet yang mencirikan bahwa perusahaan tidak hanya fokus pada diri sendiri namun juga terbuka untuk mendengarkan dan terlibat bagi para penggunanya.

Analisis konten digunakan dalam penelitian ini yang dianalisis berdasarkan frekuensi tweet, followers and followings, friend behaviour, the retweets and public messages. Hasil penelitian bahwa masih belum efektif digunakan dari potensi interaktivitas twitter dimana fitur interaktivitas masih belum optimal dimanfaatkan oleh organisasi. Twitter juga menyediakan fitur yang berbeda pada organisasi yang memungkinkan dapat melakukan tweet lebih dari 140 karakter, dengan penggunaan penyingkat hyperlink, hashtag, video dan foto. Berdasarkan hasil penelitian yang dilakukan dari analisis konten 5352 tweet pada perusahaan terbesar ditemukan bahwa perusahaan tidak memanfaatkan peluang yang signifikan untuk membangun hubungan dengan pemangku kepentingan. Meskipun perusahaan memiliki komunikasi dengan penambahan tweet lebih dari 140 karakter, namun perusahaan gagal untuk memanfaatkan fitur secara efektif untuk meningkatkan interaktivitas dan membangun jaringan sosial. Kemudian, pada aspek following dan followers, selama periode empat bulan, 6 dari 14 perusahaan tidak melakukan followback kepada pengikurnya, sedangkan membuat ikatan timbal balik dengan para pengikut merupakan cara organisasi memberikan respons positif bagi pengguna. Selama periode empat bulan juga ditemukan bahwa frekuensi perusahaan mengirimkan tweets selama satu minggu hanya 3 tweets yang mengindikasikan bahwa ketika tweet dihasilkan tidak banyak, maka RT juga tidak banyak.

Hasil menekankan bahwa perusahaan menggunakan SNS twitter sebagai alat komunikasi satu arah dan mengabaikan potensi interaktivitas dan stakeholder engagement. Sedangkan retweet berkontribusi untuk membangun interaksi publik sehingga dapat membantu suara orangorang baru ke dalam organisasi atau perusahaan (Boyd, et al., 2010). Kemudian penggunaan hyperlink dan hashtag juga ditemui bahwa hampir sepertiga perusahaan melakukan tweet berisi hyperlink yang tidak berhubungan langsung dengan perusahan. Sehingga seharusnya perusahaan dapat menggunakan fitur yang disediakan Twitter (hyperlink dan hashtag agar tercipta partisipasi interaktif, sehingga mendorong pertumbuhan komunikasi yang dialogis. Diperlukan strategi komunikasi bagi perusahaan untuk mempengaruhi awareness dari penggguna melalui kehadiran aktif pada SNS untuk meningkatkan keuntungan perusahaan, mencegah krisis citra perusahaan, hingga membangun kepercayaan bagi para pemangku kepentingan. SNS menawarkan cara bagi perusahaan untuk menjangkau khalayak yang besar, dan memanfaatkan potensi interaktivitas yang ditawarkan platform.

Arora, A., et al. (2019) melakukan penelitian pada Measuring social media influencer index insights from facebook, Twitter and Instagram. Penelitian ini mengidentifikasi indeks influencer di seluruh platform media sosial Facebook, Twitter dan Instagram. SNS membentuk cara interaksi yang baru dalam proses komunikasi dan keterlibatan termasuk para pemangku kepentingan. Adapun studi terdahulu diketahui bahwa konten yang dibagi oleh influencer dapat 
berpengaruh pada pengikut dan penonton (Neystad, et al dalam Arora 2019). Diketahui pada masing-masing platform memiliki fungsi dasar jaringan yang berbeda. Facebook digunakan dalam membangun jaringan, Instagram dan Twitter digunakan untuk media publikasi jaringan. Diketahui bahwa saat ini selebriti memposting dan memanfaatkan platform-platform tersebut. Dengan adanya pertumbuhan SNS yang semakin meningkat, brand dalam organisasi juga menggunakan selebriti memanfaatkan platform ini untuk meningkatkan keterlibatan pelanggan demi menjangkau audiens dengan basis yang lebih besar. Platform menjadi semakin populer di masyarakat karena berhasil memfasilitasi adanya kolaborasi, keterlibatan dan dampak drastis pada reputasi brand organisasi (Kim \& Ko, dalam Arora, et al, 2019).

Fitur-fitur yang disediakan pada masing-masing platform menentukan dampak bagi konsumen. Penelitian mengkaji masing-masing fitur pada platform diukur berdasarkan overall footprint, kecepatan engagement per jam dan harian, engagement outreach, sentimen audiens serta posting rate. Hasil menunjukan bahwa engagement, penjangkauan sentimen serta pertumbuhan menjadi peran kunci yang berpengaruh dalam menentukan selebriti. Implikasi praktis dari masing-masing platform dapat dijadikan pertimbangan untuk menentukan dan identifikasi mengenai keterlibatan penjangkauan yang lebih besar yang dapat digunakan berbagai aspek, mulai dari manajemen komunikasi, pemasaran di media sosial hingga ecommerce.

Kasus Kontemporer di Indonesia: Peran Social Networking Sites dalam Meningkatkan Stakeholder Engagement di Indonesia

Peneliti mengambil mengenai konteks Social Networking Sites di Indonesia dalam meningkatkan Stakeholder Engagement. Pada platform Instagram Pengaruh Customer Engagement Melalui Media Sosial Instagram terhadap Kepercayaan Merek. Pengaruh signifikan dihasilkan dari tiga variabel pada kepercayaan merk Shopee di media sosial. Pertama adalah variabel brand connection, merupakan hubungan personal yang terbangun antara customer dengan merk brand Shopee. Variabel kedua adalah contingency interactivity yang meliputi kegiatan atau aktivitas konsumen dalam melakukan interaksi seperti memberikan like, komen, repost dan share dalam instagram Shopee. Variabel terakhir adalah company attitude yakni kemampuan perusahaan untuk menunjukan sikap baik seperti mempublikasikan stabilitas finansial sehingga dapat bersaing dengan kompetitor. Hasil penelitian menunjukan bahwa SNS berperan dapat meningkatkan keterlibatan pelanggan dan berpengaruh signifikan terhadap kepercayaan brand Shopee (Mahayani, C.O., et al, 2019).

Lebih lanjut peran SNS pada platform instagram dilakukan oleh Sudira, H., et al. (2019) menganalisis sentimen Instagram untuk mengeksplorasi kepuasan pelanggan pada penyedia jasa pembayaran di Indonesia. Instagram merupakan SNS yang menyediakan informasi dan bersifat menghibur. penelitian ini menggunakan data mining karena sebelumnya banyak riset yang mengumpulkan data tekstual melalui twitter, sehingga saat ini Instagram merupakan salah satu SNS yang populer dan lebih banyak wawasan serta data yang dapat diekstraksi yang memberi dampak bagi para stakeholder. Data mining berhubungan dengan algoritma yang berorientasi pada analisis sentiman yang berkaitan dengan pendapat berupa produk, layanan, topik, emosi. Berdasarkan hasil penelitian diketahui bahwa Go-Pay menjadi penyedia layanan dengan kualitas layanan direpresentasikan dengan adanya komentar yang positif. Kemudian pada penyedia layanan lainnya yakni LinkAja dan OVO cenderung memiliki sentimen yang netral. Implikasi praktis bagi kehumasan adalah bahwa dalam membangun strategi komunikasi dengan stakeholder pada instagram dan media sosial lainnya harus dapat melebur secara taktis agar 
sentimen negatif yang berhubungan dengan perusahaan dapat diatasi dengan baik dan citra perusahaan dapat terbangun secara positif.

Penelitian pada Youtube dilakukan oleh Maulana, et al (2020) yang berjudul Measuring YouTube Channel Subscriber Loyalty: The Role of Quality, Corporate Image and Viewer Satisfaction. Penelitian tersebut mengeksplorasi kualitas konten yang dipublikasi pada saluran Youtube dalam meningkatkan kepuasan pelanggan. Youtube menjadi SNS yang dimanfaatkan oleh perusahaan Rans Entertainment di bidang hiburan dan jasa berorientasi pada pemasaran digital. Penelitian menggunakan metode survei yang menjadi penonton channel youtube channel Rans Entertainment. Saat ini Yotube channel Rans Entertainment memiliki 15 juta subscriber dan semakin populer dengan jumlah penonton yang tinggi. Konten yang diunggah bukan menjadi faktor pertama yang menarik penonton, namun adanya citra positif yang dibentuk perusahaan memberikan kontribusi yang signifikan bagi penonton. Sehingga dengan adanya hal tersebut, mendorong terciptanya kepuasan pelanggan. Pembentukan loyalitas atas adanya sikap, perilaku yang berkelanjutan. Penelitian menunjukan terdapat hasil yang signifikan antara kualitas konten dengan citra dan kepuasan pelanggan. Kemudian, kepuasan pelanggan berpengaruh positif pada loyalitas pelanggan.

\section{KESIMPULAN}

Peran Social Networking Sites dalam komunikasi yang berlangsung menjadi lebih mudah terutama untuk membangun hubungan dengan stakeholder, menciptakan engagement dengan pelanggan, serta dapat memberikan informasi juga pengawasan informasi dalam rangka menjaga citra dan reputasi pada perusahaan. Berdasarkan hasil telaah literatur perusahan menggunakan SNS melalui Facebook, Instagram, Twitter, Youtube sebagai alat untuk meningkatkan engagement pemangku kepentingan. Pemangku kepentingan atau stakeholder perusahaan terdiri dari stakeholder internal meliputi organisasi itu sendiri seperti karyawan, pemilik bisnis serta stakeholder eksternal meliputi pelanggan atau customer, kompetitor, komunitas atau masyarakat secara umum.

Strategi komunikasi diperlukan untuk membangun kehadiran aktif pada SNS untuk meningkatkan keuntungan perusahaan, mencegah krisis citra perusahaan, hingga membangun kepercayaan bagi para pemangku kepentingan. SNS membentuk cara interaksi yang baru dalam proses komunikasi dan keterlibatan termasuk para pemangku kepentingan. Adanya konsep mengenai engagement, penjangkauan sentimen serta pertumbuhan pada SNS menjadi peran kunci untuk identifikasi mengenai keterlibatan penjangkauan yang lebih besar yang dapat digunakan berbagai aspek, mulai dari manajemen komunikasi, pemasaran di media sosial hingga e-commerce yang dijalankan oleh praktisi kehumasan dan komunikasi korporat.

Social Networking Sites pada Facebook dimiliki perusahaan dapat mengukur matriks dari sisi pemangku kepentingan yaitu: 1) reaktivitas, dialog dan stakeholder; 2) social legitimacy dan voluntary disclosure; 3) stakeholder moods. Engagement dari pemangku kepentingan dapat dilihat dari penggunaan fitur likes, berbagi, dan komentar pada postingan. Social Networking Sites Facebook sebagai alat yang potensial untuk menilai kinerja perusahaan, menilai partisipasi pemangku kepentingan, menilai strategi pemasaran di Facebook, menilai strategi komunikasi, dan reputasi perusahaan secara online baik produk maupun layanan. Pada platform Youtube, konten dan kualitas dari produk yang dipublikasi mendorong terciptanya citra positif dan kepuasan pelanggan. Adanya kepuasan pelanggan kemudian memicu pembentukan loyalitas atas adanya sikap, perilaku yang berkelanjutan. 
Pada platform instagram, tingkat kepuasan dapat dilihat melalui sentimen yang muncul. Aktivitas online yang digunakan oleh pemangku kepentingan berhubungan dengan reputasi perusahaan. Diantara aktivitas keterlibatan pemangku kepentingan, indikator yang signifikan dari reputasi organisasi adalah adanya komentar positif dan negatif. Publik yang aktif menjadi sumber utama dalam pendistribusian informasi sehingga melalui SNS, nilai-nilai yang berhubungan dengan organisasi dapat diperluas dan menentukan besaran juga arah organisasi. SNS juga berperan dalam membangun koneksi, hubungan relasional antara pelanggan. Setelah tercipta hubungan (koneksi) antara pembeli, penjual dan perusahaan maka proses selanjutnya adalah interaksi. Apabila interaksi telah tercipta, selanjutnya kepuasan dapat diciptakan. Social Networking Sites berperan untuk mengukur matriks bagi stakeholder, menilai kinerja perusahaan, menilai partisipasi stakeholder, menilai strategi pemasaran, membangun hubungan relasional, hingga pembentukan loyalitas pelanggan.

Rekomendasi teoritis bagi penelitian selanjutnya adalah dapat mengeksplorasi secara lebih dalam mengenai perkembangan peran Social Networking Sites dengan membandingkan masing-masing platform seperti instagram, youtube, twitter dalam peningkatan stakeholder engagement secara komprehensif dengan menggunakan systematic review. Adapun implikasi praktis penelitian ini dapat digunakan sebagai pertimbangan mengenai peran pentingnya peran Social Networking Sites sebagai alat dengan potensi yang tinggi yang dapat digunakan untuk meningkatkan engagement dengan pemangku kepentingan, menilai kinerja perusahaan, menilai partisipasi pemangku kepentingan, menilai strategi komunikasi, sehingga hubungan antara organisasi dan pemangku kepentingan dapat berjalan dengan baik dan menghasilkan citra serta reputasi perusahaan yang positif.

\section{DAFTAR PUSTAKA}

Arora A, et al. 2019. "Measuring Social Media Influencer Index- Insights from Facebook, Twitter and Instagram," Journal of Retailing and Consumer Services 49, no. March (2019): 86-101, https://doi.org/10.1016/j.jretconser.2019.03.012.

Bonsón, E, and Ratkai M. 2013. "A Set of Metrics to Assess Stakeholder Engagement and Social Legitimacy on a Corporate Facebook Page.” Online Information Review 37 (5): 787-803. https://doi.org/10.1108/OIR-03-2012-0054.

Boyd, Danah M., and Nicole B. Ellison. 2007. "Social Network Sites: Definition, History, and Scholarship." Journal of Computer-Mediated Communication 13 (1): 210-30. https://doi.org/10.1111/j.1083-6101.2007.00393.x.

Bryman, Alan. (2012). Social Research Methods 4th Edition. USA: United States by Oxford University Press.

Castells, Manuel. 2009. "Communications Power," 137. Oxford: Oxford University Press.

Coleman, Stephen. 2013. "The Internet and the Opening Upof Political Space". https://doi.org/10.1002/9781118321607.ch25.

Cornelissen, Joep. 2014. Corporate Communication: A Guide to Theory and Practice. Sage.

Ginting, S and Rahmalinda F. 2018. "Peran Public Relations Kantor Bupati Aceh Tamiang." http://e0journal.sari-mutiara.ac.id/index.php/JLM/article/dwonload/1044/867/.

Ginting, S, and Simamora N. 2018. "Peran Public Relations Pt Coca-Cola Amatil Indonesia Medan Dalam Membangun Citra Positif Perusahaan Di Kelurahan Martubung Kecamatan Medan Labuhan Kota Medan.” Jurnal Lensa Mutiara Komunikasi 2 (1): 215. http://e-journal.sari-mutiara.ac.id/index.php/JLMI/article/view/556. 
Ji Y G, et al. 2016. "Staking Reputation on Stakeholders: How Does Stakeholders' Facebook Engagement Help or Ruin a Company's Reputation?” Public Relations Review 43 (1): 201-10. https://doi.org/10.1016/j.pubrev.2016.12.004.

Liu, Y, and Xiangxiang Y. 2010. "A Review of Social Network Sites : Definition, Experience and Applications." The Conference on Web Based Business Management, 749-52. http://dx.doi.org/10.1016/j.pubrev.2016.12.004.

Mahayani, O C, et al. 2019. "Pengaruh Customer Engagement Melalui Media Sosial terhadap Kepercayaan Merek.” Jurnal Pengembangan Teknologi Informasi dan Ilmu Komputer 3 (4): 3301-3310.

Mamic, L I, and Almaraz, A I. 2013. "How the Larger Corporations Engage with Stakeholders through Twitter." International Journal of Market Research 55 (6): 851-72. https://doi.org/10.2501/ijmr-2013-070.

Maulana E, et al. 2020. "The International Journal of Social Sciences World Measuring YouTube Channel Subscriber Loyalty: The Role of Quality, Corporate Image and Viewer Satisfaction" 2 (2): 32-39. https://doi.org/10.5281/zenodo.4020017\.

Neuman, W. Lawrence. (2014). Social Research Methods 7th Edition. USA: Pearson Education. Purwandini, D A, and Irwansyah. 2018. "Corporate Communication in The Industry Era 4.0." Jurnal Ilmu Sosial 17 (1): 53-69. https://doi.org/10.14710/jis.17.1.2018.53-63.

Sashi, C. M. 2012. "Customer Engagement, Buyer-Seller Relationships, and Social Media." Management Decision 50 (2): 253-72. https://doi.org/10.1108/00251741211203551.

Sudira, H, et al. 2019. "Instagram Sentiment Analysis with Naive Bayes and KNN: Exploring Customer Satisfaction of Digital Payment Services in Indonesia." 2019 International Workshop on Big Data and Information Security, IWBIS 2019, 21-26. https://doi.org/10.1109/IWBIS.2019.8935700.

Sugianto, A, and, Sembiring W A. 2018. "Pengaruh Kampanye Public Relations Terhadap Sikap Positif Khalayak." Jurnal Lensa Mutiara Komunikasi 2 (1): 45-60. http://114.7.97.221/index.php/JLMI/article/view/560. 